\title{
PENGARUH MODEL PROBLEM BASED LEARNING DENGAN STRATEGI EVERYONE IS A TEACHER HERE TERHADAP KEMAMPUAN KOMUNIKASI MATEMATIS DAN SELF-CONFIDENCE SISWA SMP
}

\author{
Taufik Rahman', Nisa Fauzia ${ }^{2}$ \\ 1,2 Universitas Pasundan \\ taufikpmat@unpas.ac.id
}

\begin{abstract}
Mathematical communication ability is an important ability in learning mathematics where students interact directly with mathematics through mathematical communication, but in reality students' mathematical communication skills are still low, because student confidence is still low too, so self-confidence is needed. Alternative learning that can improve mathematical communication skills and self-confidence is the learning model Problem Based Learning (PBL) with the strategy Everyone is a Teacher Here (ETH). The objectives of this study are: 1) to find out whether the improvement in mathematical communication skills of students who obtain PBL models with the ETH strategy is higher than students who obtain conventional learning; 2) whether the self-confidence of students who obtain PBL with the ETH strategy is better than students who obtain conventional learning; 3) whether there is a positive correlation between mathematical communication skills and self-confidence of students who obtain PBL with the ETH strategy. The method used is quasi experiment. The population in this study were all eight grade students of SMPN 1 Baleendah with a sample of two classes chosen at random. The instrument used in the study was a test of the type of description of mathematical communication skills and attitude scale questions containing statements about self-confidence. The results showed that: 1) The improvement of students' mathematical communication skills using PBL learning models with the ETH strategy was higher than students using conventional models; 2) Self-confidence of students who use PBL learning models with ETH strategies is better than students' self-confidence using conventional models; 3) There is a positive correlation between students' mathematical communication and self-confidence of students who obtain PBL learning with the ETH strategy.
\end{abstract}

Keywords: Mathematical Communiaction, Self-confidence, Problem Based Learning, Everyone is a Teacher Here

\begin{abstract}
ABSTRAK Kemampuan komunikasi matematis merupakan kemampuan yang penting dalam pembelajaran matematika dimana siswa berinteraksi langsung dengan matematika melalui komunikasi matematis namun kenyataannya kemampuan komunikasi matematis siswa masih rendah hal itu dikarenakan kepercayaan diri siswa masih rendah pula, untuk itu dibutuhkan self-confidence. Alternatif pembelajaran yang dapat meningkatkan kemampuan komunikasi matematis dan self-confidence adalah model pembelajaran Problem Based Learning (PBL) dengan stategi Everyone is a Teacher Here (ETH). Tujuan penelitian ini adalah: 1) mengetahui apakah peningkatan kemampuan komunikasi matematis siswa yang memperoleh model PBL dengan strategi ETH lebih tinggi daripada siswa yang memperoleh pembelajaran konvensional; 2) apakah self-confidence siswa yang memperoleh PBL dengan strategi ETH
\end{abstract}


lebih baik daripada siswa yang memperoleh pembelajaran konvensional; 3) apakah terdapat korelasi positif antara kemampuan komunikasi matematis dan self-confidence siswa yang memperoleh PBL dengan strategi ETH. Metode yang digunakan adalah kuasi eksperimen. Populasi dalam penelitian ini adalah seluruh siswa kelas VIII SMPN 1 Baleendah dengan sampel sebanyak dua kelas yang dipilih secara acak. Instrumen yang digunakan dalam penelitian berupa tes tipe uraian soal-soal kemampuan komunikasi matematis dan skala sikap berisikan pernyataan-pernyataan mengenai self-confidence. Hasil penelitian menunjukkan bahwa: 1) Peningkatan kemampuan komunikasi matematis siswa yang menggunakan model pembelajaran PBL dengan strategi ETH lebih tinggi daripada siswa yang menggunakan model konvensional; 2) Self-confidence siswa yang menggunakan model pembelajaran PBL dengan strategi ETH lebih baik daripada self-confidence siswa yang menggunakan model konvensional; 3) Terdapat korelasi positif antara komunikasi matematis siswa dan selfconfidence siswa yang memperoleh pembelajaran PBL dengan strategi ETH.

Kata-kata kunci: Komunikasi Matematis, Self-confidence, Problem Based Learning, Everyone is a Teacher Here

\section{PENDAHULUAN}

Lampiran Permendikbud nomor 58 tahun 2014 tentang kurikulum tahun 2013 dijelaskan bahwa mata pelajaran matematika bertujuan agar peserta didik mendapatkan beberapa hal salah satunya yaitu mengomunikasikan gagasan dengan simbol, tabel, diagram, atau media lain untuk menjelaskan keadaan atau masalah. Berdasarkan tujuan di atas, disadari bahwa kemampuan komunikasi matematis adalah suatu tujuan yang harus dicapai. NCTM atau National Council of Teachers of Mathematics (2004) merumuskan kemampuan pembelajaran matematika yang disebut mathematical power (daya matematika) meliputi: (a) belajar untuk berkomunikasi (mathematical communication), (b) belajar untuk bernalar (mathematical reasoning), (c) belajar untuk memecahkan masalah (mathematical problem solving), (d) belajar untuk mengaitkan ide (mathematical connection), dan (e) belajar untuk merepresentatif.

Pentingnya pemilikan kemampuan komunikasi matematis dijelaskan oleh Yonandi (dalam Sumarmo, 2012) yaitu: a) Matematika adalah bahasa esensial yang tidak hanya sebagai alat berpikir, menemukan rumus, menyelesaikan masalah, atau menyimpulkan saja, namun matematika juga memiliki nilai yang tak terbatas untuk menyatakan beragam idea secara jelas, teliti, dan tepat; b) Matematika dan belajar matematika adalah jantungnya kegiatan sosial manusia, misalnya dalam pembelajaran matematika interaksi antara guru dan siswa, antara siswa dan siswa, antara bahan pelajaran matematika dan siswa adalah faktor-faktor terpenting dalam memajukan potensi siswa. Kemudian Yonandi (dalam Sumarmo, 2012) mengemukakan pentingnya memiliki kemampuan komunikasi matematis yakni: membantu siswa menjalankan cara siswa berpikir, sebagai alat untuk menilai pemahaman siswa, membantu siswa mengorganisasi pengetahuan matematik mereka, membantu siswa membangun pengetahuan matematikanya, meningkatkan kemampuan pemecahan masalah, memajukan penalarannya, membangun kemampuan diri, dan meningkatkan keterampilan sosialnya, sehingga bermanfaat dalam mendirikan suatu komunitas matematik. 
Pada penjelasan tersebut, dapat disimpulkan bahwa kemampuan komunikasi matematis merupakan kemampuan yang penting dalam pembelajaran matematika, dimana siswa berinteraksi langsung dengan matematika melalui komunikasi matematis yakni berfikir, merespon, berdiskusi, menjelaskan, menulis, membaca, mendengarkan dan mengkaji konsep-konsep matematika, sehingga matematika lebih mudah dipahami siswa (Lutfianannisak, 2018).

Namun, fakta di lapangan bahwa kemampuan komunikasi matematis belum optimal. Programme for International Student Assessment atau PISA (2016) menyatakan Indonesia berada pada peringkat ke-63 dari 96 negara. Sedangkan rata-rata skor matematika Indonesia 375. Padahal rata-rata skor keseluruhan 496, hal ini jauh dari rata-rata peringkat 3 besar yakni Shanghai. TIMSS dalam Riyanto (2016) menyatakan siswa Indonesia berada pada posisi 35 dari 46 negara yang disurvei dengan skor 411 dari kisaran rata-rata skor yang diperoleh oleh setiap Negara 400625. Untuk permasalahan matematika yang menyangkut komunikasi matematis, siswa Indonesia hanya berhasil benar 5\% dan masih jauh di bawah Singapura, Korea, dan Taiwan yang mencapai $50 \%$. Hal ini sesuai dengan penelitian yang dilakukan oleh Purnama (2016) yang menyatakan, "Rendahnya tingkat komunikasi matematis siswa di lapangan perlu mendapatkan perhatian yang lebih dari berbagai pihak. Khususnya bagi guru matematika itu sendiri. Kreativitas guru dalam menyampaikan pembelajaran sangatlah dibutuhkan untuk mendukung siswa aktif dalam proses pembelajaran.

Ningrum (2015) mengatakan "Kemampuan komunikasi matematis siswa yang dilakukan peneliti di salah satu SMP di Kota Bandung, menunjukkan bahwa terdapat 24 dari 38 siswa yang mendapat nilai dibawah rata-rata dari skor maksimal 100. Hal tersebut menunjukkan bahwa masih ada siswa di Kota bandung yang memiliki kemampuan komunikasi yang kurang". Pada penjelasan tersebut, dapat disimpulkan bahwa kemampuan komunikasi matematis merupakan kemampuan yang penting dalam pembelajaran matematika, dimana siswa berinteraksi langsung dan berdiskusi matematika melalui kemampuan komunikasi matematis.

Berdasarkan tujuan pembelajaran, di samping untuk meningkatkan kemampuan kognitif siswa yaitu kemampuan komunikasi matematis, siswa harus memiliki kemampuan afektif. Salah satu kemampuan afektif yang telah diteliti adalah Selfconfidence yaitu percaya diri, Self-confidence merupakan sikap positif seorang individu yang merasa memiliki kompetensi atau kemampuan untuk mengembangkan penilaian positif baik terhadap dirinya maupun lingkungan. Selfconfidence percaya akan kemampuan sendiri yang memadai dan menyadari kemampuan yang dimiliki, serta dapat memanfaatkan secara tepat (Putri, 2017). Menurut Syam (2017) salah satu cara untuk menumbuhkan self-confidence adalah dengan memberikan suasana atau kondisi yang demokratis, yaitu individu dilatih untuk dapat mengemukakan pendapat kepada pihak lain melalui interaksi sosial, dilatih berpikir mandiri dan diberi suasana yang aman sehingga individu tidak takut berbuat kesalahan. 
Self-confidence sangat penting bagi siswa agar berhasil dalam belajar matematika. Oleh sebab itu, rasa percaya diri perlu dimiliki dan dikembangkan pada setiap siswa. Perlunya self-confidence dimiliki siswa dalam belajar matematika ternyata tidak dibarengi dengan fakta yang ada. Masih banyak siswa yang memiliki self-confidence yang rendah. Hal itu ditunjukkan oleh hasil studi TIMSS (2012) yang menyatakan bahwa dalam skala internasional hanya $14 \%$ siswa yang memiliki self-confidence tinggi terkait kemampuan matematikanya. Sedangkan $45 \%$ siswa termasuk dalam kategori sedang, dan $41 \%$ sisanya termasuk dalam kategori rendah. Hal serupa juga terjadi pada siswa di Indonesia. Hanya 3\% siswa yang memiliki self-confidence tinggi dalam matematika, sedangkan 52\% termasuk dalam kategori siswa dengan selfconfidence sedang dan $45 \%$ termasuk dalam kategori siswa dengan self-confidence rendah. Widiyanti (2014) mengatakan "Rendahnya percaya diri siswa antara lain adalah masih rendahnya siswa yang berani mengemukakan pendapatnya yaitu sebanyak 2 siswa $(6,67 \%)$, masih rendahnya siswa yang mau bertanya jika ada halhal yang belum dipahami yaitu sebanyak 4 siswa (13,33\%), dan masih rendahnya siswa yang berani mengerjakan soal di depan kelas yaitu sebanyak 10 siswa (33,33\%)". Berdasarkan fakta-fakta di atas, melihat belum optimalnya kemampuan komunikasi matematis dan Self-confidence siswa, maka peneliti mengajukan solusi pembelajaran dengan menggunakan model Problem Based Learning dengan strategi Everyone is a Teacher Here. Problem Based Learning (PBL) merupakan "strategi dimana siswa belajar melalui permasalahan praktis yang berhubungan dengan kehidupan nyata. Kemudian siswa diarahkan untuk meyelesaikan permasalahan yang sedang dibahas melalui serangkaian pembelajaran yang sistematis" Rubi (2012). Sedangkan strategi Everyone is a Teacher Here (ETH) merupakan salah satu strategi dalam pembelajaran aktif (active learning) yang menuntut siswa untuk mengeluarkan potensi yang dimilikinya dan berpartisipasi aktif dalam pembelajaran.

Berdasarkan hal-hal di atas, dirasakan perlu upaya untuk mengungkapkan apakah model Problem Based Learning dengan Strategi Everyone is a Teacher Here dapat meningkatkan kemampuan komunikasi matematis siswa dan Self-confidence. Atas dasar tersebut maka dilakukan penelitian untuk mengetahui Pengaruh Model Problem Based Learning dengan Strategi Everyone is a Teacher Here terhadap Kemampuan Komunikasi Matematis dan self-confidence Siswa SMP. Sehingga tujuan dari penelitian ini adalah untuk mengetahui apakah peningkatan kemampuan komunikasi matematis siswa yang memperoleh model pembelajaran Problem Based Learning dengan strategi Everyone is a Teacher Here lebih tinggi daripada siswa yang memperoleh model pembelajaran konvensional; apakah self-confidence siswa yang menggunakan model Problem Based Learning dengan strategi Everyone is a Teacher Here lebih baik daripada siswa yang memperoleh model pembelajaran konvensional; apakah terdapat korelasi positif antara kemampuan komunikasi dan self-confidence siswa yang memperoleh model Problem Based Learning dengan strategi Everyone is a Teacher Here. 


\section{METODE PENELITIAN}

Dalam penelitian ini pendekatan yang digunakan adalah penelitian kuantitatif, karena ingin menjawab dari suatu perumusan masalah yang ada. Untuk menjawab perumusan masalah tersebut perlu digunakan konsep atau teori sehingga dapat dirumuskan hipotesis, selanjutnya hipotesis tersebut diujikan pada populasi atau sampel tertentu yang representatif (mewakili) melalui pengumpulan data lapangan. Dalam pengumpulan data tersebut yang berasal dari sampel menggunakan instrumen-instrumen yang dapat mengukur keberhasilan penelitian. Lalu data yang telah terkumpul dianalisis secara kuantitatif dengan menggunakan statistik deskriptif atau inferensial, setelah itu tkita bisa dapat menyimpulkan hipotesis yang dirumuskan sebelumnya apakah terbukti atau tidak. Hal ini sesuai dengan definisi penelitian kuantitatif menurut Sugiyono $(2010, \mathrm{hlm}$. 14) Metode penelitian kuantitatif dapat diartikan sebagai metode penelitian yang berlandaskan pada filsafat positivisme, digunakan untuk meneliti pada populasi atau sampel tertentu, teknik pengambilan sampel pada umumnya dilakukan secara acak (random), pengumpulan data menggunakan instrumen penelitian, analisis data bersifat kuantitatif/ statistik dengan tujuan untuk menguji hipotesis yang telah ditetapkan.

Selain penelitian yang bersifat kuantitatif, metode yang digunakan dalam penelitian ini adalah metode eksperimen semu (quasi experiment), penggunaan metode ini bertujuan untuk mengetahui pengaruh variabel bebas terhadap variabel terikat. Ruseffendi (2010) berpendapat bahwa penelitian eksperimen adalah penelitian yang benar-benar untuk melihat hubungan sebab-akibat, perlakuan yang kita lakukan terhadap variabel bebas kita lihat hasilnya pada variabel terikat. Variabel bebas yang dimaksud dalam penelitian ini adalah model pembelajaran PBL dengan ETH sedangkan variabel terikatnya adalah kemampuan komunikasi matematis dan selfconfidence siswa. Instrumen penelitian digunakan untuk memperoleh data, baik kualitatif maupun kuantitatif.

Instrumen untuk memperoleh data kualitiatif (non-tes) adalah angket, sedangkan data kuantitatif diperoleh melalui tes (pretest dan postest). Soal yang digunakan dalam pretest dan posttest adalah sama. Sedangkan instrumen non-tes yang digunakan adalah skala Likert untuk mengukur tingkat positif atau negatifnya sikap siswa terhadap penerapan model pembelajaran PBL dengan ETH dalam pembelajaran matematika. Instrumen non-tes hanya diberikan untuk kelas eksperimen pada akhir penelitian setelah posttest. Analisis data yang digunakan dalam penelitian ini meliputi statistik deskriptif, uji normalitas distribusi, uji homogenitas dua varians, uji-† dan uji korelasi menggunakan Pearson.

\section{HASIL DAN PEMBAHASAN}

Data yang diperoleh dalam penelitian ini adalah data nilai tes kemampuan komunikasi matematis siswa dan data hasil self-confidence siswa. Hasil dari penelitian berupa data yang terdiri dari data kuantitatif. Data kuantitatif berupa data hasil kemampuan komunikasi matematis siswa pada dua kelas sampel, yaitu kelas eksperimen dan kelas kontrol, serta dari pengisian angket self-confidence siswa. 


\section{Analisis Data Nilai Tes Kemampuan Komunikasi Matematis Siswa}

Analisis data peningkatan kemampuan komunikasi matematis siswa ini dapat menggunakan data indeks gain (gain ternormalisasi). Analisis indeks gain dilakukan untuk mengetahui lebih detail mengenai taraf signifikansi perubahan yang terjadi setelah proses pembelajaran yng dilakukan. Setelah dilakukan pengolahan data hasil pretes dan postes kelas eksperimen dan kelas kontrol, diperoleh statistik deskriptif nilai gain ternormalisasi yang terdiri dari nilai maksimum, nilai minimum, rata-rata, dan simpangan baku. Di bawah ini disajikan statistik deskriptif dari data skor gain kelas eksperimen dan kelas kontrol.

Tabel 1. Statistik Deskriptif Gain Ternormalisasi Kedua Kelas

\begin{tabular}{cccccc}
\hline \multirow{2}{*}{ Kelas } & \multicolumn{5}{c}{ Parameter } \\
\cline { 2 - 6 } & $\mathrm{n}$ & Min & Max & $\bar{x}$ & $\sigma$ \\
\hline Eksperimen & 30 & 0.32 & 1.00 & 0.66 & 0.19 \\
\hline Kontrol & 30 & 0.24 & 0.81 & 0.54 & 0.18 \\
\hline
\end{tabular}

Berdasarkan tabel di atas, rata-rata peningkatan kemampuan kedua kelas masuk dalam kategori sedang. Untuk melihat perbedaan kedua kelas secara detail berikut hasil statitistif inferensial untuk data indeks gain (gain ternormalisasi) kemampuan komunikasi matematis siswa.

Tabel 2. Hasil Data Normalitas Gain Tenormalisasi Kedua Kelas

\begin{tabular}{ccc}
\hline \multirow{2}{*}{ Kelas } & \multicolumn{2}{c}{ Shapiro Wilk } \\
\cline { 2 - 3 } & Df & Sig \\
\hline Eksperimen & 30 & 0.404 \\
\hline Kontrol & 30 & 0.116 \\
\hline
\end{tabular}

Berdasarkan hasil perhitungan dengan menggunakan uji Shapiro-Wilk pada Tabel 2 signifikansi data skor gain ternormalisasi untuk kelas eksperimen adalah 0,404 dan signifikansi data skor gain ternormalisasi untuk kelas kontrol adalah 0,1 16. Karena nilai signifikansi kedua kelas lebih dari 0,05 jadi kedua kelas merupakan sampel berdistribusi normal. Setelah melakukan uji normalitas dan hasilnya data tersebut berdistribusi normal, maka selanjutnya adalah melakukan uji homogenitas varians dengan uji levene's test for equality variansces. Tampilan hasilnya terlihat seperti pada Tabel 3.

\section{Tabel 3. Hasil Uji Homogenitas Dua Varians Gain Ternormalisasi Kedua Kelas}

\begin{tabular}{cc}
\hline Levene Statistic & Sig. \\
\hline 0.002 & 0.968 \\
\hline
\end{tabular}

Berdasarkan Tabel 3, diperoleh bahwa nilai signifikansi sebesar 0,968 lebih besar dari 0,05 maka data mempunyai varians sama, sehingga dapat disimpulkan bahwa data skor gain ternormalisasi mempunyai varians sama atau homogen. Karena kedua sampel (kelas eksperimen dan kelas kontrol) berdistribusi normal dan memiliki varians yang homogen maka dilanjutkan dengan uji- $\dagger$ yaitu dengan menggunakan independent sample t-test untuk menguji kesamaan dua rata-rata, dengan taraf 
signifikansi 0,05 . Hasil uji independent sample t-test tampilan hasilnya dapat dilihat pada Tabel 4.

\begin{tabular}{|c|c|}
\hline & $\begin{array}{l}\text { t-test for Equality of } \\
\text { means }\end{array}$ \\
\hline & Sig. (2-tailed) \\
\hline $\begin{array}{c}\text { Equal variances } \\
\text { assumed }\end{array}$ & 0.013 \\
\hline $\begin{array}{c}\text { Equal variances } \\
\text { not assumed }\end{array}$ & 0.013 \\
\hline
\end{tabular}

Pada Tabel 4 diperoleh bahwa nilai signifikansi (2 tailed) adalah 0,013, sehingga nilai signifkansi yang diajukan adalah $1 / 2$ dari 0,013 yaitu 0,0065 . Nilai signifikansi tersebut kurang dari 0,05 maka $\mathrm{HO}$ ditolak. Dapat disimpulkan bahwa rata-rata peningkatan kemampuan komunikasi matematis kelas eksperimen yang menggunakan pembelajaran Problem Based Learning dengan strategi Everyone is a Teacher Here lebih tinggi secara signifikan daripada kelas kontrol yang menggunakan pembelajaran konvensional.

\section{Analisis Data Angket Self-Confidence}

Setelah memberi perlakuan dengan pembelajaran Problem Based Learning dengan strategi Everyone is a Teacher Here pada kelas eksperimen dan pembelajaran konvensional pada kelas kontrol, untuk mengetahui self-confidence siswa mana yang lebih baik antara kelas eksperimen dan kelas kontrol, maka pada masing-masing kelas diberikan angket di akhir pembelajaran.

Analisis data pertama yang dilakukan adalah analisis statistik deskriptif yang meliputi nilai maksimum, nilai minimum, rata-rata, dan simpangan baku. Dibawah ini disajikan statistik data hasil sikap siswa untuk kelas eksperimen dan kelas kontrol menggunakan program SPSS versi 20.0 for Windows yang disajikan pada Tabel 5.

Tabel 5. Statistik Deskriptif Data Skala Self-Confidence Kedua Kelas

\begin{tabular}{cccccc}
\hline & \multicolumn{5}{c}{ Parameter } \\
\cline { 2 - 6 } & $\mathrm{n}$ & Min & Max & $\bar{x}$ & $\sigma$ \\
\hline Kontrol & 30 & 60.69 & 95.18 & 73.54 & 9.53 \\
\hline Eksperimen & 30 & 60.73 & 100.22 & 80.07 & 11.07 \\
\hline Valid N (listwise) & 30 & & & & \\
\hline
\end{tabular}

Dari Tabel 5 diperoleh bahwa rata-rata hasil skala self-confidence siswa dari kelas eksperimen adalah 80,07 sedangkan kelas kontrol adalah 73,54. Sehingga dapat disimpulkan bahwa nilai rata-rata kelas eksperimen lebih tinggi daripada kelas kontrol. Untuk memperkuat hasil dari analisis deskriptif, langkah selanjutnya adalah pengujian statistik inferensial. Berikut adalah hasil uji kesamaan dua rerata untuk data angket self-confidence siswa. 
Tabel 6. Hasil Uji Kesamaan Dua Rerata Skala Self-Confidence Kedua Kelas

\begin{tabular}{cc}
\hline & t-test for Equality of means \\
\cline { 2 - 2 } & Sig. (2-tailed) \\
\hline $\begin{array}{c}\text { Equal variances } \\
\text { assumed }\end{array}$ & 0.017 \\
\hline $\begin{array}{c}\text { Equal variances } \\
\text { not assumed }\end{array}$ & 0.017 \\
\hline
\end{tabular}

Pada Tabel 6 diperoleh bahwa nilai signifikansi (2 tailed) adalah 0,017 sehingga nilai signifkansi yang diajukan adalah $1 / 2$ dari 0,017 yaitu 0,0085 . Nilai signifikansi tersebut kurang dari 0,05 maka HO ditolak. Dapat disimpulkan bahwa self-confidence siswa yang memperoleh pembelajaran Problem based Learning dengan strategi Everyone is a Teacher Here lebih baik daripada siswa yang memperoleh pembelajaran konvensional.

\section{Analisis Korelasi}

Analisis Data Korelasi Setelah memberi perlakuan dengan pembelajaran Problem Based Learning dengan strategi Everyone is a Teacher Here pada kelas eksperimen, maka dilakukan uji korelasi untuk mengetahui apakah terdapat korelasi antara selfconfidence dengan kemampuan komunikasi matematis siswa pada kelas eksperimen. Karena data hasil postes kelas eksperimen berdistribusi normal maka pengujian korelasi ini menggunakan Pearson pada program SPSS 20.00 for windows. Berikut adalah hasilnya

Tabel 7. Hasil Uji Korelasi Kelas Eksperimen

\begin{tabular}{llcc}
\hline & & $\begin{array}{c}\text { Kemampuan } \\
\text { komunikasi } \\
\text { matematis }\end{array}$ & $\begin{array}{c}\text { Angket Self- } \\
\text { Confidence }\end{array}$ \\
\hline $\begin{array}{l}\text { Kemampuan } \\
\text { komunikasi } \\
\text { matematis }\end{array}$ & Pearson Correlation & 1 & 0.98 \\
\cline { 2 - 4 } $\begin{array}{l}\text { Angket Self- } \\
\text { Confidence }\end{array}$ & $\mathrm{N}$ (2-tailed) & 30 & 0.00 \\
\cline { 2 - 4 } & Searson Correlation & 0.98 & 30 \\
\hline & $\mathrm{N}$ & 0.00 & 1 \\
\hline
\end{tabular}

Dari tabel 7 dapat dilihat signifikansinya adalah 0,000, itu menunjukkan bahwa nilai signifikansi $<0,05$ maka $\mathrm{H}_{0}$ ditolak dan $\mathrm{H}_{a}$ diterima. Maka dapat disimpulkan terdapat korelasi positif antara self-confidence dengan kemampuan komunikasi matematis pada kelas eksperimen. Dengan koefisien korelasi 0,982 maka hubungan korelasi tersebut termasuk kategori sangat kuat. Dan koefisien determinasi yang besarnya adalah kuadrat dari koefisien korelasi $r 2=0,9822=0,964324$. 
Pembahasan hasil penelitian ini didasarkan pada faktor-faktor yang dicermati dalam studi ini. Faktor-faktor tersebut meliputi kegiatan model pembelajaran PBL dengan ETH, kemampuan komunikasi matematis, dan self-confidence siswa.

Berdasarkan hasil analisis indeks gain, uji normalitas kedua kelas berdistribusi normal sehingga dilanjutkan dengan uji homogenitas dan kedua kelas menunjukkan data yang homogen setelah itu dilanjutkan dengan uji perbedaan dua rerata (Uji-†) yaitu menggunakan Independent Sample t-Test dan hasilnya kemampuan rata-rata peningkatan kemampuan komunikasi matematis kelas eksperimen yang menggunakan pembelajaran Problem Based Learning dengan strategi Everyone is a Teacher Here lebih tinggi secara signifikan daripada kelas kontrol yang menggunakan pembelajaran konvensional dan peningkatan kemampuan komunikasi matematis siswa pada kelas eksperimen dan kelas kontrol tergolong dalam kategori sedang. Peningkatan kemampuan komunikasi matematis dapat dilihat dari beberapa jawaban postes yang telah dikumpulkan oleh siswa dari kelas eksperimen dan kelas kontrol. Dalam soal nomor 1 diberikan soal sebagai berikut, "Diketahui Surya membeli 3 buku dan 2 penggaris seharga Rp13.000,00. Jika Ani membeli 2 kali lipat buku dan 3 kali lipat penggaris dari yang dibeli Surya maka ia harus membayar Rp30.000,00. Berapakah harga yang harus dibayar oleh Siti, jika ia membeli 10 Buku dan 3 penggaris yang sama?". Berikut merupakan salah satu hasil jawaban siswa dalam mengerjakan soal postes kemampuan komunikasi matematis:

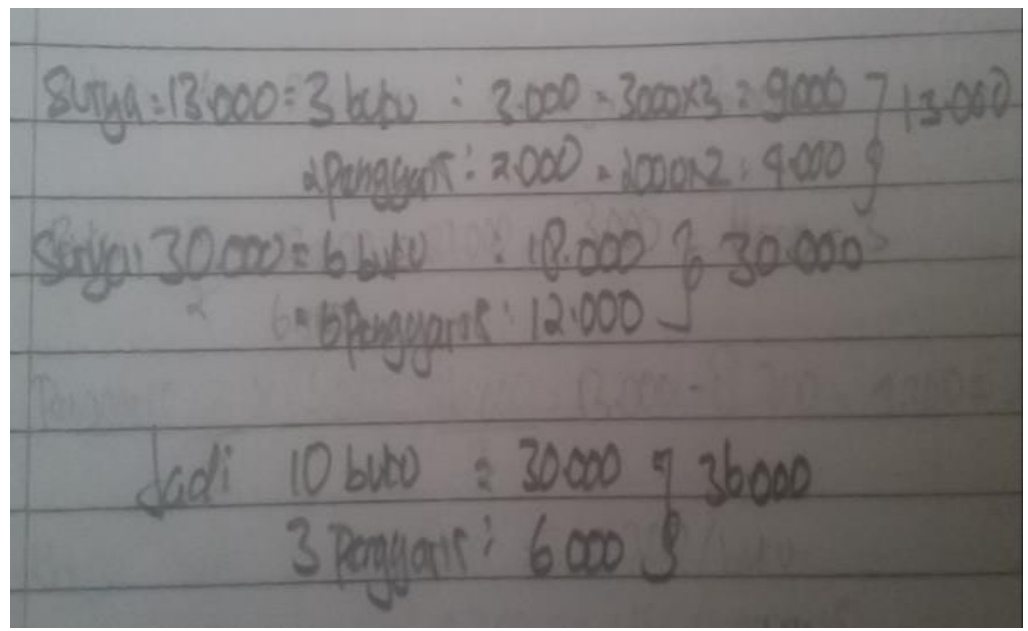

Gambar 1 Hasil Jawaban Siswa Kelas Kontrol

Pada Gambar 1 dapat dilihat bahwa siswa sudah mampu menjawab soal hanya saja jawabannya kurang tepat dan mengkomunikasikannya masih sebatas apa yang ada dalam soal. Hal ini terjadi karena siswa belum terbiasa mengkomunikasikan pemahamannya, siswa cenderung malas dalam menjawab jawaban secara terstruktur dikarenakan kemampuan komunikasi siswa yang masih rendah sehingga siswa masih sulit mengubah suatu situasi, gambar atau grafik soal matematika ke dalam ide atau model matematika. Berikut adalah hasil jawaban siswa dalam mengerjakan soal postes kemampuan komunikasi matematis: 


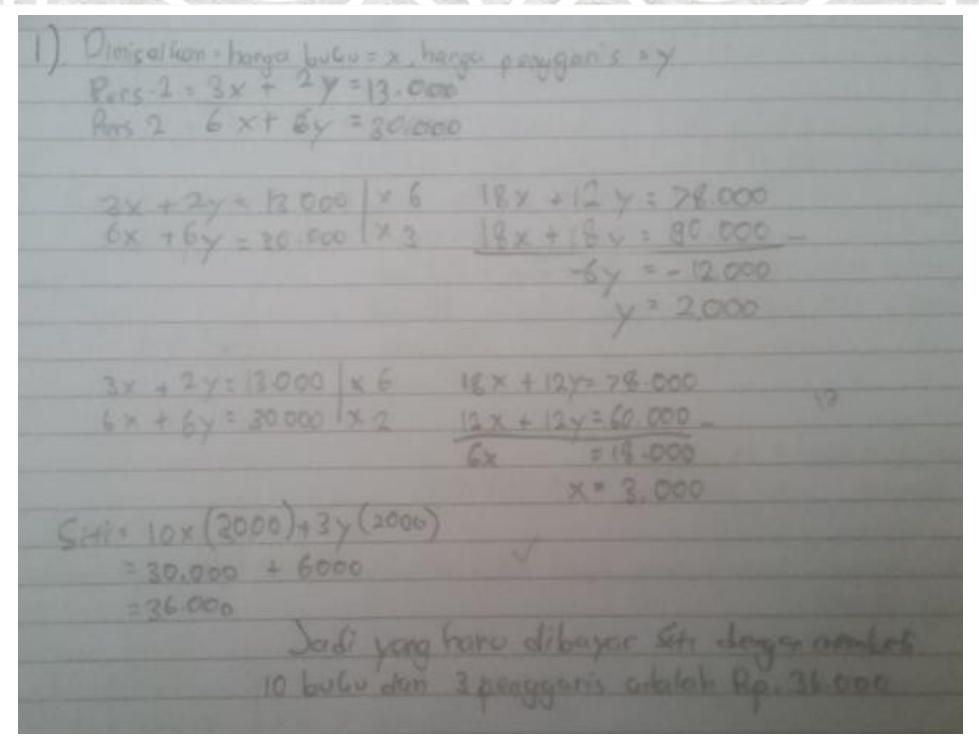

Gambar 2 Hasil Jawaban Siswa Kelas Eksperimen

Setelah diberikan pembelajaran Problem Based Learning dengan strategi Everyone is a Teacher Here, pada Gambar 2 terlihat bahwa siswa telah mampu berkomunikasi matematis dengan baik, serta siswa sudah mampu menyajikan pernyataan matematika dalam bentuk tulisan dan menyelesaikan persoalan yang diberikan. Problem Based Learning dengan strategi Everyone is a Teacher Here dapat meningkatkan kemampuan komunikasi matematis siswa, karena fase pada langkah pembelajaran Problem Based Learning sangat berkaitan dengan indikator kemampuan komunikasi matematis. Temuan peneliti juga didukung oleh hasil penelitian yang dilakukan sebelumnya oleh Alzianina dkk (2016) yang melakukan penelitian tentang Pengaruh Model Problem Based Learning Terhadap Kemampuan Komunikasi Matematis Siswa. Dimana Alzianina dkk (2016) menyimpulkan bahwa terdapat pengaruh model Problem Based Learning (PBL) terhadap kemampuan komunikasi matematis siswa. Hasil tersebut juga sesuai dengan apa yang ditemukan oleh Nurbaiti (2016) Peningkatan kemampuan komunikasi matematis siswa yang mendapatkan pembelajaran dengan model Problem-Based Learning lebih baik daripada siswa yang mendapatkan pembelajaran dengan model konvensional.

Berdasarkan hasil penelitian self-confidence yang telah dilakukan dan hasil analisis skala sikap self-confidence yang diberikan kepada siswa yang mendapatkan model pembelajaran Problem Based Learning dengan strategi Everyone is a Teacher Here menunjukkan sikap yang positif, dalam artian siswa lebih merasa percaya diri dalam belajar. Hal ini didasarkan pada jawaban siswa yang lebih cenderung memilih jawaban setuju untuk pernyataan positif dan tidak setuju untuk pernyataan negatif. Sejalan dengan pendapat Ruseffendi (2006) mengatakan "sikap positif seorang siswa adalah dapat mengikuti pelajaran dengan sungguh-sungguh, dapat menyelesaikan tugas yang diberikan dengan baik, tuntas dan tepat watu, berpartisipasi aktif, dan dapat merespon dengan baik tantangan yang diberikan".

Hasil uji korelasi dilakukan untuk mengukur kekuatan dan arah hubungan antar dua variabel atau lebih. Dalam penelitian ini uji korelasi dilakukan untuk mengukur 
kekuatan dan hubungan antara kemampuan komunikasi matematis dan selfconfidence siswa. Dari hasil analisis uji korelasi didapat bahwa pembelajaran matematika dengan menggunakan model pembelajaran Problem Based Learning dengan strategi Everyone is a Teacher Here yang telah dilakukan memberikan pengaruh terhadap korelasi antara kemampuan komunikasi matematis dan selfconfidence siswa. Melalui pembelajaran ini kemampuan komunikasi dan selfconfidence siswa memiliki koefisien korelasi positif. Sehingga dapat disimpulkan terdapat korelasi positif antara self-confidence dengan kemampuan komunikasi matematis pada kelas eksperimen dengan kategori korelasi tersebut termasuk kategori korelasi sangat kuat. Artinya jika skala sikap self-confidence siswa tinggi maka akan meningkatkan kemampuan komunikasi matematis siswa.

\section{KESIMPULAN DAN SARAN}

Berdasarkan penelitian yang dilaksanakan mengenai pengaruh model pembelajaran Problem Based Learning dengan strategi Everyone is a Teacher Here terhadap kemampuan komunikasi matematis dan self-confidence siswa SMP diperoleh kesimpulan sebagai berikut:

1. Peningkatan kemampuan komunikasi matematis siswa yang memperoleh model Problem Based Learning dengan strategi Everyone is a Teacher Here lebih tinggi daripada kemampuan komunikasi matematis siswa yang memperoleh pembelajaran konvensional.

2. Self-confidence siswa yang memperoleh pembelajaran Problem Based Learning dengan strategi Everyone is a Teacher Here lebih baik daripada self-confidence siswa yang memperoleh pembelajaran konvensional.

3. Terdapat korelasi positif yang sangat kuat antara komunikasi matematis siswa dan self-confidence siswa yang memperoleh pembelajaran Problem Based Learning dengan strategi Everyone is a Teacher Here.

\section{UCAPAN TERIMAKASIH}

Kami mengucapkan terimakasih kepada FKIP UNPAS yang telah mendanai serta memfasilitasi penelitian ini sehingga penelitian berjalan dengan lancar, serta kepada semua pihak yang telah membantu dalam pelaksanaan penelitian.

\section{DAFTAR PUSTAKA}

Alzianina,E dkk. (2016). Pengaruh Model Problem Based Learning Terhadap Kemampuan Komunikasi Matematis siswa. Jurnal Pendidikan Matematika UNILA. 4(2).

Hake, R.R. (1999). Analyzing Change/Gain Score. Woodland Hills Dept. of Physics. Indiana University. [Online]. http://physic.indiana.edu/sdi/analyzing. ChangeGain: pdf (Diakses tanggal 28 Maret 2018)

Kemendikbud. (2014). Permendikbud Nomor 58 tahun 2014 tentang Kurikulum SMP. 
Lutfianannisak. (2018). Kemampuan Komunikasi Matematis Siswa dalam Menyelesaikan Soal Materi Komposisi Fungsi Ditinjau dari Kemampuan Matematika. Jurnal Tadris Matematika. 1(1): 1-8

NCTM. (2004). Overview: Standards for School Mathematics. http://standards. nctm.org/document/chapter3/pr ob.htm (diakses pada tanggal 28 Maret 2018)

Ningrum, A. S. (2015). Pengaruh Strategi Relating, Expencing, Applying, Cooperating, Transpering (REACT) Terhadap Sikap dan Peningkatan Kemampuan Komunikasi Matematis Siswa. Bandung: Skripsi UPI Bandung.

Nurbaiti, I. S. (2016). Pengaruh Pendekatan Problem Based Learning Terhadap Kemampuan Komunikasi Matematis Dan Motivasi Belajar Siswa. Jurnal Pena Ilmiah. 1(1).

OECD. 2016. PISA 2015 Results in Fokus : Excellence and Equity in Education. Volume I. https://www.oecd.org/pisa/pisa-2015-results-infocus.pdf

Purnama, L. I. (2016). Kemampuan Komunikasi Matematis Siswa Ditinjau Melalui Model Pembelajaran Kooperatif Tipe Complete Sentence Dan Team Quiz. Jurnal Pendidikan Matematika. 10(1):27-43

Putri, Riyanti. (2017) Penerapan Model Pembelajaran REACT (Relating, Experiencing, Applying, Cooperating, Transfering) untuk Meningkatkan Kemampuan Komunikasi Matematis dan SelfConfidence Siswa SMP. Skripsi(S1) thesis, FKIP UNPAS.

Riyanto, A (2016). Pengaruh Strategi Pembelajaran Think-Talk-Write (TTW) terhadp Kemampuan Komunikasi Matematis Siswa SMA. Skripsi FKIP UNPAS. Bandung: Tidak diterbitkan.

Rubi, A. P. (2012). Penerapan Model Pembelajaran Berbasis Masalah (Problem Based Learning) untuk Meningkatkan Prestasi Belajar Siswa pada Mata Diklat Praktik Dasar Intalasi Listrik (PDIL) di SMK Muhammadiyah Yogyakarta. Jurnal Pendidikan Teknik Mekatronika. 1(1):17-25

Ruseffendi, E.T. (2006). Pengantar kepada Membantu Guru Mengembangkan Kompetensinya dalam Pengajaran Matematika untuk Menigkatkan CBSA. Bandung: Tarsito.

Ruseffendi, E.T. (2010). Dasar-Dasar Penelitian Pendidikan \& Bidang Non-Eksakta Lainnya. Bandung: Tarsito

Sugiyono. (2010). Statistika Untuk Penelitian. Bandung: CV Alfabeta.

Sumarmo,U.(2012). Pendidikan Karakter serta Pengembangan Berpikir dan Disposisi Matematik dalam pembelajaran Matematika. Makalah disajikan dalam Seminar Pendidikan Matematika di NTT tanggal 25 Februari 2012.

Syam, A. (2017). Pengaruh Kepercayaan Diri (Self Confidence) Berbasis Kaderisasi Imm Terhadap Prestasi Belajar Mahasiswa. Jurnal Biotek. 5 (1) : 87-102

TIMSS. (2012). TIMSS 2011 International Results in Mathematics. Chestnut Hill: TIMSS \& PIRLS International Study Center.

Widiyanti, T. Y. (2014). Peningkatan kepercayaan Diri dan kemandirian Siswa dalam Pembelajaran Matematika melalui pembelajaran Attention Relevance Confidence Satisfaction (ARCS). Skripsi UMS Jawa Tengah: Tidak diterbitkan. 